\title{
PENERAPAN BUDAYA INOVASI DENGAN MENGADOPSI METODE KAIZEN (CONTINUOUS IMPROVEMENT) DI PT. PETROSIDA GRESIK
}

\author{
Oldive Meigres Zenit ${ }^{1}$, Sukaris ${ }^{2}$ \\ 1,2Departemen Manajemen, Fakultas Ekonomi dan Bisnis, \\ Universitas Muhammadiyah Gresik, Gresik, Jawa Timur, Indonesia \\ meigreszenit@yahoo.co.id ${ }^{1}$, sukaris21@umg.ac.id ${ }^{2}$
}

\begin{abstract}
Background - Innovation culture is a very important thing to be applied to a company with the purpose of maintaining the existence and survival of the company. The level of success in doing this innovation significantly depends on the ability, skills and interpreting the rapidly changing environment. In addition, employee involvement also influences the success of innovation. Innovation itself is often associated with KAIZEN or in Japanese terms it means "continuous improvement" which emphasizes human effort, morals, communication, training, cooperation, empowerment and self-discipline.

Objective - The purpose of this study was to determine the strategy carried out by PT. Petrosida Gresik in motivating its employees to implement an innovation culture and to identify inhibiting factors in its application and what efforts must be made to minimize these obstacles.

Design: This study uses qualitative research methods and the informants in this study are employees who are the originators of the application of an innovation culture in the company, and innovators who always innovate in their work. Validity test of the data by using source triangulation and member checking.

Findings - From the results of this study, the researcher can conclude that the application of the innovation culture in this company has a positive impact on the survival of the company.

Research implications - This study provides a contribution in human resource management related to corporate culture.

Research limitations - Cannot interviews with the Manager of Human Resource Department because timing of the research during the Covid19 pandemic.
\end{abstract}

Keywords: Innovation, Culture, KAIZEN (Continuous Improvement)

\begin{abstract}
Abstrak
Latar Belakang - Budaya inovasi merupakan hal yang sangat penting untuk diterapkan pada suatu perusahaan untuk bisa mempertahankan eksistensi serta keberlangsungan hidup perusahaan. Keberhasilan melakukan inovasi tergantung secara signifikan pada kemampuan, keterampilan dan menafsirkan lingkungan berubah dengan cepat. Selain itu keterlibatan karyawan juga mempengaruhi keberhasilan dalam inovasi. Inovasi seringkali dihubungkan dengan KAIZEN dalam istilah Jepang, yang memiliki arti "perbaikan berkesinambungan" yang menekankan pada upaya manusia, moral, komunikasi, pelatihan, kerjasama, pemberdayaan dan disiplin diri.

Tujuan - Tujuan dari penelitian ini adalah untuk mengetahui strategi yang dilakukan PT. Petrosida Gresik dalam memotivasi karyawannya untuk menerapkan budaya inovasi serta mengidentifikasi faktor penghambat penerapannya dan upaya yang dilakukan untuk meminimalisir hambatan tersebut.
\end{abstract}

http://dx.doi.org/10.30587/mahasiswamanajemen.v1i2.1903

Program Studi Manajemen Universitas Muhammadiyah Gresik Jawa Timur Indonesia 
Desain / metodologi / pendekatan - Penelitian ini menggunakan metode penelitian kualitatif dan informan dalam penelitian ini adalah karyawan yang menjadi pencetus adanya penerapan budaya inovasi di perusahaan serta innovator yang selalu melakukan inovasi dalam setiap pekerjaannya. Uji keabsahan data penelitian ini menggunakan triangulasi sumber serta membercheck.

Temuan - Dari hasil penelitian ini, peneliti mendapat kesimpulan bahwa penerapan budaya inovasi di perusahaan dapat berdampak positif terhadap keberlangsungan hidup perusahaan.

Implikasi penelitian - Penelitian ini memberikan sumbangsi dalam manajemen sumber daya manusia berkaitan dengan budaya perusahaan.

Batasan penelitian - Tidak dapat melakukan wawancara dengan Manager Departemen SDM dan Umum dikarenakan waktu pelaksanaan penelitian dimasa pandemi covid19.

Kata kunci : Inovasi, Budaya, KAIZEN (Continuous Improvement)

\section{PENDAHULUAN}

Memasuki era industri 4.0 beberapa perusahaan BUMN di Indonesia yang bergerak di bidang agroindustri, menyadari bahwa peran inovasi dan budaya inovasi menjadi sangat penting untuk diterapkan di suatu perusahaan, karena dengan dilakukannya inovasi perusahaan akan mampu bersaing dan bertahan. Sebab seiring perkembangan zaman, apabila suatu perusahaan terlambat dalam mengambil keputusan untuk melakukan inovasi, maka dalam jangka waktu yang tidak lama perusahaan tersebut akan kehilangan masa kejayaannya. Fenomena ini juga diiringi dengan ditetapkannya hari inovasi nasional disetiap tanggal 1 November oleh Handi Irawan D selaku Chairman Tera Foundation yang meraih Penghargaan Rekor Bisnis (ReBi). Hari inovasi nasional ini akan diperingati oleh seluruh individu maupun organisasi pemilik merek yang tujuannya adalah mengingatkan kembali para pelaku bisnis dan perusahaan Indonesia untuk menciptakan budaya inovatif, produk dan layanan inovatif untuk kehidupan yang lebih baik bagi masyarakat Indonesia.

Inovasi merupakan hal terpenting bagi suatu organisasi atau perusahaan untuk bisa mempertahankan eksistensi maupun keberlangsungan hidup perusahaan. Karena seiring berjalannya waktu, teknologi dan ilmu pengetahuan selalu mengalami kemajuan dan perkembangan, dengan berkembangnya kedua hal tersebut, manusia semakin dimudahkan dalam melakukan sesuatu. Keberhasilan melakukan inovasi tergantung secara signifikan pada kemampuan, keterampilan dan menafsirkan lingkungan berubah dengan cepat. Selain itu keterlibatan karyawan juga mempengaruhi keberhasilan dalam kinerja peruahaan (Alkusani dan Sukaris, 2019; Sukaris et al., 2020). Ketika perusahaan 
memiliki niat untuk menjadi inovatif yang mereka butuhkan adalah mendorong interaksi karyawan dan menunjukkan bahwa ide karyawan dihargai. Kerja sama tim juga memainkan bagian yang berpotensi penting dalam proses inovasi yang memungkinkan berbagi pengetahuan, pengembangan kepercayaan dan mengatasi hambatan ruang dan organisasi. Dapat disimpulkan bahwa, hanya mereka yang memiliki budaya inovasi dalam organisasinya yang mampu bertahan dan menjadi pemenang dalam sebuah kompetisi industri.

Inovasi adalah hasil dari penerapan budaya inovasi, yaitu proses penciptaan perilaku inovatif agar individunya terbiasa untuk melakukan sebuah inovasi. Inovasi dan budaya inovasi merupakan hal yang sangat berkaitan, karena dengan adanya budaya inovasi, orang-orang didalamnya akan terbiasa melakukan maupun menciptakan hal-hal yang baru agar memudahkan dan mempercepat cara kerja mereka dan dengan terciptanya metode kerja yang otomatis produktivitas di perusahaan juga akan meningkat, yang mana hal tersebut akan berdampak positif bagi perusahaan, baik di bidang produksi, pemasaran maupun keuangan perusahaan.

Inovasi seringkali dihubungkan dengan KAIZEN dalam istilah Jepang, yang mempunyai arti "perbaikan berkesinambungan". KAIZEN menekankan pada upaya manusia, moral, komunikasi, pelatihan, kerjasama, pemberdayaan dan disiplin diri. KAIZEN sendiri mempunyai fungsi pemeliharaan dan perbaikan standar. Fungsi pemeliharaan yang dimaksud adalah pembentukan dan menjaga standar operasional yang telah ditetapkan agar dipatuhi oleh seluruh karyawan. Untuk fungsi perbaikannya adalah perbaikan yang mengahasilkan perubahan yang signifikan dan dilakukan secara berkesinambungan. Dalam penerapannya di perusahaan, perubahan yang berkesinambungan yang dimaksud melibatkan seluruh pekerjanya dari manajemen tingkat atas hingga manajemen tingkat bawah.

Menurut Knox (2002), elemen utama yang terkandung dalam budaya perusahaan terdapat pada efektivitas organisasi dalam mengembangkan sistem dan menerapkan strategi yang dilakukan melalui komitmen dan keahlian para karyawannya. Dobni (2008) menyatakan, terdapat empat faktor yang penting dalam budaya yang mempengaruhi inovasi. Awal kebutuhan karakteristik budaya masyarakat berinovasi yaitu mempunyai niat untuk menjadi inovasi, infrastruktur untuk mendukung inovasi, orientasi pasar untuk inovasi, hingga konteks implementasi untuk inovasi. 
Budaya inovasi dan KAIZEN tidak akan bisa berjalan lancar apabila sebagian karyawan tidak mampu menerima dan menerapkan budaya inovasi, hal ini merupakan suatu tantangan maupun hambatan bagi perusahaan untuk mencapai visi yang telah ditetapkan oleh perusahaan.. Apabila suatu perusahaan ingin tetap berada di jalur kompetisi industri dan tidak tersingkir, maka budaya inovasi harus diterapkan di perusahaan tersebut.

Objek peneliti adalah salah satu perusahaan agroindustri terkemuka di Indonesia, yaitu PT Petrosida Gresik. Perusahaan ini adalah anak perusahaan dari PT Petrokimia Gresik yang menjadi salah satu perusahaan yang termasuk dalam PIHC (Pupuk Indonesia Holding Company). Perusahaan ini menerapkan budaya inovasi di setiap proses kerjanya, baik di bagian manufaktur maupun di bagian administrasi. Dari hasil wawancara singkat peneliti dengan salah satu staf unit inovasi dan knowledge management PT Petrosida Gresik, Roys Dwinugroho, diketahui bahwa jumlah inovasi yang dilakukan oleh karyawan PT Petrosida Gresik dari tahun ke tahun selalu mengalami peningkatan.

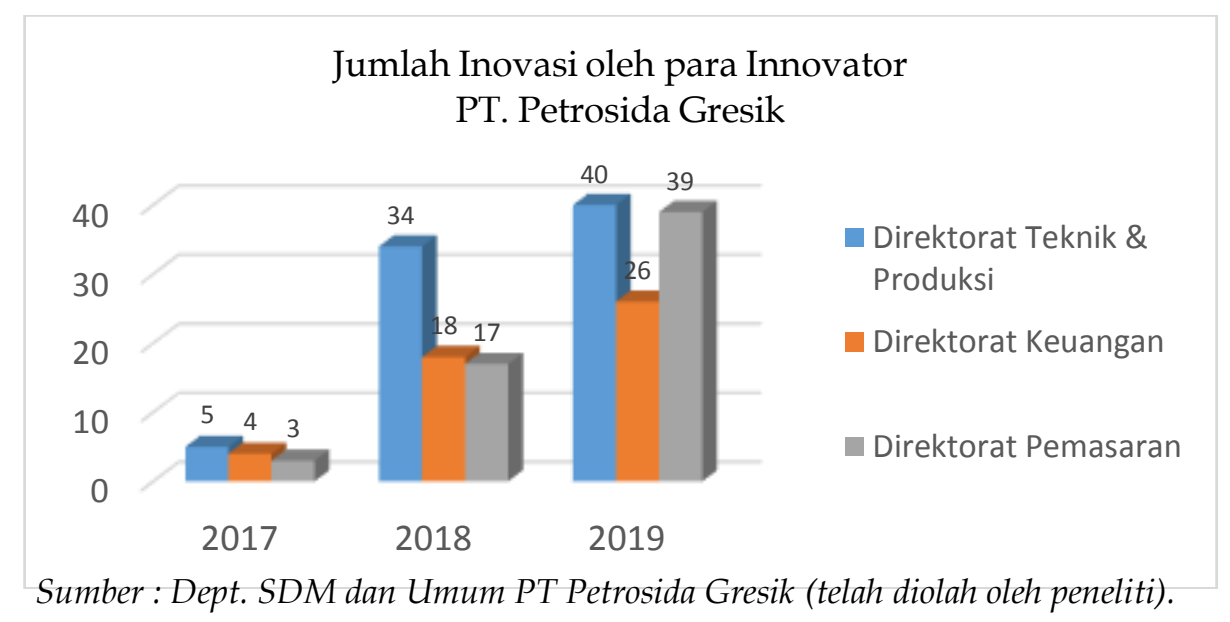

Gambar 1. Grafik Peningkatan Jumlah Judul Inovasi tahun 2017 hingga 2019

Data diatas menjelaskan, masing - masing direktorat mengalami peningkatan inovasi yang signifikan. Karena pentingnya budaya inovasi bagi keberlangsungan hidup perusahaan agar mampu bersaing dalam dunia bisnis, maka peneliti tertarik untuk meneliti strategi apa yang digunakan oleh PT Petrosida Gresik dalam proses penerapan budaya inovasinya di perusahaan. 


\section{TINJAUAN PUSTAKA}

\section{Inovasi}

Rediyono dan Ujianto (2013:103) Cepatnya perubahan lingkungan eksternal mendorong perlunya pemahaman terhadap budaya organisasi dan eksistensi budaya organisasi yang sesuai. Inovasi memerlukan pihak-pihak yang berkomitmen untuk mewujudkannya. Komitmen seluruh pihak untuk berpartisipasi aktif dan mendukung perubahan yang dilakukan, sebab kegagalan terciptanya suatu inovasi kebanyakan terjadi karena ketidakpedulian angota organisasi pada inovasi.

\section{Budaya Inovasi}

Menurut Wan Ismail dan Majid (2007), budaya inovasi adalah hasil dari keseluruhan interaksi multifaset antara dimensi kunci dan nilai-nilai yang tertanam dalam budaya organisasi. Nilai-nilai ini termasuk fleksibilitas, visi ke depan, pemberdayaan, apresiasi ide, toleransi resiko, komunikasi, dorongan, dan pengambilan keputusan bersama. Oleh karena itu, proses inovasi tidak akan menjadi aktivitas yang dapat dibagi, sebaliknya, harus terjadi dalam budaya yang terdiri dari seperangkat nilai yang dianut secara koheren untuk memfasilitasi praktik inovasi yang sedang berlangsung.

Budaya inovasi dalam organisasi perlu ditanamkan, karena dipandang sebagai kebutuhan vital, dan organisasi perlu menyediakan dukungan yang diperlukan untuk melancarkan proses inovasi tersebut. Dari sudut pandang praktis, mengelola inovasi penting untuk kelangsungan hidup organisasi bisnis, lembaga pemerintah maupun lembaga pengetahuan. Ini menyiratkan pada upaya memberikan karyawan kesempatan untuk mengeksplorasi dan bereksperimen, sedangkan manajemen memberikan dukungan melalui dorongan aktif atas perilaku inovatif karyawan tersebut (Wan Ismail dan Majid, 2007:38).

\section{KAIZEN atau Perbaikan Berkesinambungan}

Cane (1998) dalam Paramita (2012:4) menjelaskan dalam bahasa Jepang, kaizen berarti perbaikan yang berkesinambungan (continuous improvement). Ciri kunci manajemen kaizen antara lain lebih memperhatikan proses dan bukan hasil, manajemen fungsional silang dan menggunakan lingkaran kualitas dan peralatan lain untuk mendukung peningkatan yang terus menerus. 
Tujuan kaizen antara lain yaitu meningkatkan QCD (Quality, Cost, Delivery) yang dimana sasaran utama dari hal-hal tersebut ialah meningkatkan kepuasan pelanggan dan meningkatkan kesetiaan konsumen. Kato dan Art Smalley (2011:38) menyatakan bahwa ada 6 langkah (Steps) dalam membuat suatu kaizen. Keenam langkah tersebut yaitu menemukan potensi perbaikan, menganalisis metode yang digunakan saat ini, mencetuskan ide original, menyusun rencana penerapan, menerapkan rencana, dan mengevaluasi metode baru.

Kaizen termasuk dalam tujuh konsep program Total Quality Management (TQM) yang efektif yang merupakan penyempurnaan dari 14 poin Edward Deming. Tujuh konsep program TQM yang efektif tersebut antara lain: Perbaikan berkesinambungan (Kaizen), Six Sigma, Pemberdayaan Pekerja, Benchmarking, Just In Time (JIT), Konsep Taguchi, dan Seven Tools Perangkat TQM, Heizer dan Render (2005:307).

\section{METODOLOGI PENELITIAN}

\section{Pendekatan Penelitian}

Pendekatan penelitian yang digunakan adalah kualitatif. Pendekatan penelitian kualitatif dilakukan dengan menjelaskan dan menguraikan secara sistematis mengenai permasalahan yang akan diteliti, sehingga dapat memberikan gambaran yang jelas mengenai objek yang akan diteliti, kemudian ditarik kesimpulan.

\section{Lokasi dan Fokus Penelitian}

Lokasi Dalam penelitian ini di PT Petrosida Gresik. Jl. KIG Raya Utara Kav.O No. 5, Kawasan Industri Gresik (KIG), Gresik 61151, Jawa Timur - Indonesia. Penelitian ini difokuskan pada penerapan budaya inovasi di PT. Petrosida Gresik

\section{Sumber Data dan Jenis Data}

Sumber data adalah asal darimana data itu diperoleh dan didapatkan oleh peneliti baik melalui observasi, wawancara, maupun dokumentasi (Suharsimi Arikunto, 2006 : 129). Adapun data yang digunakan dalam penelitian ini adalah data primer, yaitu data yang diperoleh dari lapangan langsung. Data primer dalam penelitian ini dihimpun dari wawancara mendalam (in-depth interview) kepada para innovator serta karyawan Departemen SDM dan Umum yang melakukan pengawasan di bidang inovasi \& pengembangan karyawan.yang merupakan inti dari subyek penelitian. 


\section{Teknik Pengumpulan Data}

Teknik pengumpulan data yang digunakan di dalam penelitian ini adalah wawancara.

\section{Unit Analisis}

Unit analisis yang akan diteliti atau dianalisa melalui para informan dalam penelitian ini adalah proses penerapan budaya inovasi di PT. Petrosida Gresik.

\section{Informan}

Informan yang menjadi sumber data dalam penelitian ini adalah pelaku inovasi (innovator), serta karyawan Departemen SDM dan Umum PT. Petrosida Gresik yang membimbing para innovator untuk melakukan inovasi di perusahaan serta melakukan pengawasan di bidang inovasi dan pengembangan karyawan. Teknik untuk menentukan informan yang akan dipilih oleh peneliti dalam penelitian ini menggunakan teknik purposive sampling (Sugiyono, 2017:273).

\section{Teknik Analisis Data}

Menurut Miles dan Huberman dalam Herdiansyah (2012: 164), analisis kualitatif deskriptif terdapat empat tahapan, yaitu:

1. Pengumpulan data

2. Reduksi data

3. Penyajian data (display data)

4. Penarikan kesimpulan / Verifikasi

\section{Uji Keabsahan Data}

Untuk memperoleh data yang nilai keabsahannya mempunyai validitas, maka peneliti melakukan proses Triangulasi. Dalam penelitian ini, peneliti menggunakan teknik triangulasi sumber dengan cara membandingkan dan mengecek balik derajat kepercayaan suatu informasi yang diperoleh melalui waktu dan alat yang berbeda dalam penelitian kualitatif (Moleong 2016:330 ). Data yang telah dianalisis oleh peneliti akan menghasilkan suatu kesimpulan selanjutnya dimintakan kesepakatan (member check) dengan sumber data tersebut. (Sugiyono, 2017;274). 


\section{HASIL DAN PEMBAHASAN}

Menurut teori, budaya inovasi adalah hasil dari keseluruhan interaksi multifaset antara dimensi kunci dan nilai-nilai yang tertanam dalam budaya organisasi. Nilai-nilai ini termasuk fleksibilitas, visi ke depan, pemberdayaan, apresiasi ide, toleransi resiko, komunikasi, dorongan, dan pengambilan keputusan bersama. Maka, proses inovasi tidak akan menjadi aktivitas yang dapat dibagi, sebaliknya, harus terjadi dalam budaya yang terdiri dari seperangkat nilai yang dianut secara koheren untuk memfasilitasi praktik inovasi yang sedang berlangsung (Wan Ismail dan Majid, 2007:45).

Hasil penelitian ini mengenai penerapan budaya inovasi, faktor penghambat dan upaya untuk meminimalisir menunjukkan bahwa strategi yang digunakan perusahaan untuk menerapkan budaya tersebut adalah dengan melakukan sosialisasi ke seluruh jajaran karyawan mengenai pentingnya melakukan inovasi untuk keberlangsungan hidup perusahaan. Sosialisasi yang digunakan perusahaan dari hasil penelitian ini adalah dengan diadakannya konvensi inovasi yang rutin yang diadakan setiap tahun, yang didalamnya ada ide-ide inovasi karyawan di setiap unit kerja akan di lombakan. Tujuan ini diterapkan perusahaan agar para karyawannya selalu berperilaku inovatif.

Budaya inovasi dalam organisasi perlu ditanamkan, karena dipandang sebagai kebutuhan vital, dan organisasi perlu menyediakan dukungan yang diperlukan untuk melancarkan proses tersebut. Seperti yang diucapkan oleh informan bapak Gunawan bahwa "top manajemen malah mendukung adanya budaya inovasi ini. Apalagi jajaran direksi, mereka malah seneng liat karyawan-karyawannya aktif demi kemajuan perusahaan".

Inovasi mampu menjadi motivasi kerja karyawan karena setiap karyawan mampu menciptakan metode kerja baru yang lebih mudah dan membuat mereka nyaman dalam bekerja dan mampu menjadi motivasi agar bekerja lebih giat. Harapan dari penerapan budaya ini, perusahaan dapat mengefisiensi biaya operasional perusahaan yang akan berpengaruh pada peningkatan margin perusahaan. Dalam penerapan budaya tersebut, terdapat pula kendala-kendala yang menjadi penghambat kesuksesan penerapannya. Berdasarkan hasil dari penelitian ini, ditemukan beberapa faktor yang menjadi penghambat suksesnya penerapan budaya tersebut. 
Salah satunya adalah karakter karyawan yang apabila tidak diberi perintah tidak akan jalan, karyawan yang tidak ingin maju dengan pemikiran kuno yang menganggap inovasi sebagai beban kerja tambahan, dan karyawan yang merasa perusahaan di tempat dia bekerja masih eksis jadi tidak perlu ada perubahan atau inovasi. Inovasi mampu menjadi motivasi kerja karena dengan adanya inovasi setiap karyawan mampu menciptakan metode kerja baru yang lebih mudah dan membuat mereka nyaman dalam bekerja dan mampu menjadi motivasi agar bekerja lebih giat.

\section{KESIMPULAN}

Inovasi mampu menjadi motivasi kerja karena dengan adanya inovasi setiap karyawan mampu menciptakan metode kerja baru yang lebih mudah dan membuat mereka nyaman dalam bekerja dan mampu menjadi motivasi agar bekerja lebih giat. Faktor yang menjadi penghambat saat penerapan budaya inovasi adalah karakter karyawan yang apabila tidak diberi perintah tidak akan jalan, karyawan yang tidak ingin maju dengan pemikiran kuno yang menganggap inovasi sebagai beban kerja tambahan, karyawan yang merasa perusahaan di tempat dia bekerja masih eksis jadi tidak perlu ada perubahan atau inovasi serta kebiasaan kerja di tiap departemen berbeda-beda.

Perusahaan mengatasi hambatan saat penerapan budaya inovasi dengan cara sosialisasi rutin yang terjadwal ke tiap unit kerja tentang inovasi, sharing melalui obrolan ringan tentang pentingnya melakukan inovasi untuk keberlangsungan hidup perusahaan kedepannya agar tetap eksis dan mampu bersaing hingga memberikan pendekatan kepada seluruh jajaran karyawan dengan hadiah uang tunai serta paket wisata yang akan diperoleh setelah melakukan inovasi di perusahaan.

KPI (Key Performance Indicator) digunakan untuk mengukur keefektifan strategi yang dilakukan oleh perusahaan dalam menyampaikan budaya inovasi. Serta melakukan monitoring dan evaluasi (monev) untuk mengevaluasi sejauh mana penerapan budaya inovasi telah tersampaikan kepada seluruh karyawan, dan segera menindaklanjutinya apabila terjadi kendala dalam penerapannya.

\section{REKOMENDASI}

Rekomendasi yang diberikan oleh peneliti sehubungan dengan hasil penelitian ini adalah sebagai berikut: 


\section{Bagi Perusahaan}

Perusahaan dinilai perlu memberikan reward yang berpengaruh pada jenjang karir karyawan seperti kenaikan golongan atau jabatan, untuk karyawan yang melakukan inovasi atau perubahan metode dalam bekerja lebih efektif dan efisien demi kemajuan perusahaan, agar mampu mempertahankan semangat berinovasi para karyawan.

\section{Bagi Peneliti Selanjutnya}

Bagi peneliti selanjutnya diharapkan penelitian ini dapat dijadikan pedoman dan referensi untuk melakukan penelitian lebih dalam lagi tentang budaya inovasi dengan objek dan teknik yang berbeda sebagai dasar perbandingan keefektifan strategi yang digunakan.

\section{DAFTAR PUSTAKA}

Sugiyono. (2017). Metode Penelitian Kuantitatif, Kualitatif, dan RED. Bandung : CV. Alfabeta.

Dobni, C. Brooke. (2008). Measuring innovation culture in organizations: The development of a generalized innovation culture construct using exploratory factor analysis, European Journal of Innovation Management. 11 (4) pp. 539-559.

Smalley A, Isao K. (2011). Toyota Kaizen Methods. Jakarta: Gradien Mediatama.

Heizer Jay, Render Barry. (2005). Operations Management. Jakarta: Salemba Empat.

Miles, B. Mathew dan Michael Huberman. (1992). Analisis Data Kualitatif Buku Sumber Tentang Metode-metode Baru. Jakarta: UIP.

Alkusani, A., \& Sukaris, S. (2019). Pengaruh Job-Engagement Terhadap Prilaku Withdrawal Melalui Komitmen Organisasi. Bawal Widya Riset Entrepreneurship, 2 (1), 43-51.

Cane, S. (1998) Strategi Kaizen untuk Menang Melalui Manusia: Bagaimana Menciptakan Program Sumber Daya Manusia untuk Memenangkan Persaingan dan Keuntungan. Batam: Interaksara.

Knox, S. (2002) dalam Valdo Flavian. Analisis Pengembangan Budaya Inovasi Produk Pada Perusahaan Footwear Di Sidoarjo. Jurnal Budaya Inovasi. AGORA Vol. 4, No. $2,(2016)$

Moleong, L J. (2016). Metodologi Penelitian Kualitatif Edisi Revisi. Bandung : PT. Remaja Rosdakarya 
Rediyono dan Ujianto, (2013), Mayahayati Kusumaningrum, Fani Heru Wismono, dan Rustan Amarullah. Aktualisasi Budaya Inovasi Pada Organisasi Sektor Publik. Jurnal Borneo Administrator. Volume 14 (3) (2018) : hal 252.

Suharsimi, Arikunto. (2006), Prosedur penelitian Suatu Pendekatan Praktik, Jakarta: Rineka Cipta.

Sukaris, S., Prathiwi, MP, \& Pristyadi, B. (2020). Meningkatkan Kinerja Karyawan Melalui Keterikatan, Budaya Organisasi, Dan Gaya Kepemimpinan. Equilibrium: Jurnal Ekonomi-Manajemen-Akuntansi , 16 (1), 15-21.

Wan Ismail, Wan Khairuzzaman dan Majid, Abd. (2007). Framework of the culture of innovation : A Revisit. Jurnal Kemanusiaan bil.9, Juni 2007, 38-49 